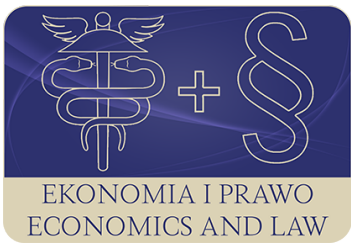

EKONOMIA I PRAWO. ECONOMICS AND LAW

Volume 20, Issue 3, September 2021

p-ISSN 1898-2255, e-ISSN 2392-1625

www.economicsandlaw.pl

ORIGINAL ARTICLE

received 30.03.2021; revised 10.09.2021; accepted 30.09.2021

Citation: Podstawka, M., \& Podstawka, Ł. (2021). Farm income and its taxation. Ekonomia i Prawo.

Economics and Law, 20(3), 603-615. https://doi.org/10.12775/EiP.2021.036.

\title{
Farm income and its taxation
}

\section{MARIAN PODSTAWKA}

corresponding author

Institute of Agricultural and Food Economics, National Research Institute, Department of Finance and Risk Management, ul. Świętokrzyska 20, 00-002 Warszawa, Poland

$\square$ marian.podstawka@ierigz.waw.pl

(D) orcid.org/0000-0002-3834-0743

\section{EUKASZ PODSTAWKA}

Warsaw Univeristy of Life Sciences, Faculty of Economics, Institute of Economics and Finance, Poland

$\nabla$ lukasz_podstawka@sggw.pl

(D) orcid.org/0000-0002-7394-0218

\begin{abstract}
Motivation: It is increasingly common to hear the opinion that farm income should be taxed with income tax, just like other types of economic activity. Currently, the level of taxation of farm income is low. As the economic power of the farm increases, the level of taxation of its income decreases. Over the years 2014-2019, no variation can be observed in the level of taxation of farm income. Certain simplified attempts to record economic events on farms, due to the fact that they receive all kinds of subsidies, are being gradually introduced by the Ministry of Agriculture and Rural Development. The time has come to carry out a reliable assessment of the income situation of farms. The calculation of income is important for making management decisions on the farm so as to optimise the production structure, costs, etc.

Aim: The objective of the study is to assess the level of income among FADN farms in various economic classes, to assess the level of taxation of income of these farms, and to present the problems related to a potential change in the taxation of agricultural activities. The study aims to show the problems related to calculating income on farms and to present the advantages and disadvantages of the existing taxes paid by farmers. Results: The result of the study is a proposal regarding tax rates in agriculture. According to the author, in the case of taxation of farm income, in order to maintain its current level of taxation, the tax rate should be $1-2 \%$. If farm income were to be taxed, the tax rate, which would not increase the current tax burden, should be $2-5 \%$.
\end{abstract}


Keywords: agricultural income; agricultural tax; FADN

JEL: H24; H25; Q14

\section{Introduction}

It is increasingly common to hear the opinion that farm income should be taxed with income tax, just like other types of economic activity. In principle, we should agree with this opinion, provided, however, that the condition for introducing income tax in agriculture is the introduction of an obligation to calculate farm income. This issue is difficult in substantive and organisational terms and also has a political context. Without reference to this last aspect, the study will present the substantive and organisational conditions associated with the calculation of farm income. The current level of taxation and proposals related to the introduction of income tax will be presented.

Certain simplified attempts to record economic events on farms, due to the fact that they receive all kinds of subsidies, are being gradually introduced by the Ministry of Agriculture and Rural Development. This is a step in the right direction, leading to transparency of the financial situation of farms. The greatest changes in this regard apply to the payment of drought compensation. It seems that in the future, this concept should be abandoned. In the market economy, in the conditions of reduced yields, compensation comes in the form of an increase in prices. Therefore, it can happen that reduced yields do not need to cause losses in farm income. For these reasons, as well as many others, the time has come to make a reliable assessment of the income situation of farms. It is not just about the issues of public expenditure, which should be organised in the event of losses in farm income. The more important issue is the fact that the calculation of income is of great importance for making management decisions on the farm so as to optimise the production structure, costs, etc. (Czyżewski, 2017).

As regards the issues related to potential changes in the taxation of farms, it should be stressed that these changes should not result in an increase in their fiscal burden. When determining income tax rates, "far-reaching restraint" should be exercised. Such solutions are applied in many EU countries with regard to the taxation of farm income.

The objective of the study is to assess the level of income among FADN farms in various economic classes. To assess the level of taxation of income of these farms. To present the problems and methods of calculating income on farms.

The following hypotheses have been adopted:

1. The level of taxation of farm income is low.

2. As the economic power of the farm increases, the level of taxation of its income decreases.

3. Over the years 2014-2019, no variation can be observed in the level of taxation of farm income. 


\section{Research methods}

The study used a descriptive and financial analysis. The results of the research have been presented using a tabular and graphical method. The charts were taken from the accounting data of farms included in the Polish FADN study sample. Information from scientific studies has also been used.

\section{Problems related to calculating income on farms}

The introduction of an obligation to calculate income on farms will probably give rise to substantive, organisational, and mental problems. The substantive problems will be associated with the adoption of a method of calculating farm income. Currently, the FADN system uses the EU method of determining income for a representative sample of Polish farms, as shown in Scheme 1. This is a unified method used in FADN research in all EU countries. This method has major disadvantages. It starts from the top (production), through internal turnover (intermediate consumption), to the bottom (family farm income).

It seems that the application of this method in agricultural practice will be difficult and complicated in organisational terms. This is mainly about the valuation of internal turnover, which is not necessary in the simplified "bottom-up" method. It can be skipped. Using this method, we can also determine the level of income on farms. Therefore, we start with the gross commodity production, together with the farm's own consumption and the increase in stocks, and then we reach the gross final production. Then, from this category we deduct the purchased inputs of agricultural origin, thus obtaining the net final production category. In turn, we deduct from it the purchased inputs of non-agricultural origin, thus obtaining the gross output category, which, less depreciation, results in the net output category. Then, by deducting lease costs, social accumulation costs (taxes, charges) and rent from this value, we obtain the agricultural income category. The graphical calculation of farm income according to this method is shown in Scheme 2.

The method of determining farm income, as described and presented in the Scheme 2, is less labour-intensive and would be more comprehensible for farmers. This does not mean that the application of this method will not cause any difficulties. These will include, for example, determining of the amount of depreciation. In order to calculate this, it is necessary to determine what is a fixed asset on the farm and what is not. It is also necessary to adopt a uniform method of valuing the assets of farms and to define who is going to carry out this activity - either the farmer him/herself or an expert. There will be even more problems related to introducing accounting on farms: among others, the breakdown of overhead costs necessary due to the functioning of the farm and the household. Taking these difficulties into account, it seems that the time has come to decide to calculate income on farms. At the beginning, we could make EU payments, e.g. investment payments, conditional upon the pres- 
entation of business plans prepared based on the results of the accounts kept on the farm. The calculation of income on farms could be used in a business insurance policy. It seems that it would be much more rational to insure against the loss of farm income rather than against drought or other random events. Income is a category synthesising all events, both those concerning technology, yields and those which are economic, i.e. include the prices of inputs or prices of agricultural products. As mentioned in the introduction, smaller production in the market economy results in reduced supply, which leads to an increase in prices. Therefore, it may happen that drought damage will occur on the farm, which does not have to translate into a reduction in its income.

\section{Taxes imposed on farms}

Currently, owners, perpetual usufructuaries, autonomous possessors of farms, and dependent possessors must pay: agricultural tax, forest tax, property tax, VAT and excise tax. On the other hand, producers who operate as part of special branches of agricultural production are taxed with PIT. As far as the agricultural tax is concerned, it has been in force since 1 January 1985 (Act on agricultural tax, 1984). The structure of the agricultural tax is based on differential rent I (a form of ground rent) and reduces its impact on the production and income results of farms. It is linear and taxes one of the elements of the potential of farms, namely, agricultural land. This potential is determined on average, at the same level in a given commune, which is classified into one of the four tax districts. If an agricultural producer makes good use of this potential, the agricultural tax will reward the producer with a bonus. This bonus will consist in the fact that the unit of revenue or income will be charged with a smaller amount of tax. If an agricultural producer makes poor use of the potential of cultivated land, the agricultural tax will be a greater burden on the producer's income (Juszczyk, 2019). In addition, the advantage of the existing agricultural tax is that it is conducive to the intensity of agricultural production and does not impede the growth of farms. This results from the fact that regardless of the size of the farm, the tax is always paid at the same rate per 1 equivalent hectare. This is equivalent to 2.5 q rye. However, it seems that despite the positive characteristics represented by the agricultural tax, it should be replaced by the income tax when we take the new objectives of the CAP into account. The new guidelines of this policy do not concern, as in the 50s and 60s, the growth of the production of food, but refer to sustainable development, climate and environmental protection. In this situation, the income tax with a moderate progression rate would be more useful to achieve these objectives. Even more so considering that agricultural tax also has disadvantages. In some situations, it may not take the farmer's fiscal capacity into account. This will happen in a situation where the farm has no income. In addition, the amount of the agricultural tax is based on the outdated classification of land and on a faulty valorisation method for the Agricultural Production Space, by means of which tax districts have been identified. The val- 
orisation method for the Agricultural Production Space took into account four elements of the natural and soil environment, i.e. soil, hydrographic conditions, agro-climate and lay of the land. Of the maximum of 122 points which could be scored by a commune with the best agricultural production conditions of this type, as many as 100 points are assigned to soils. Currently, the factor limiting the soil productivity are water resources, which are assigned only 10 points in the valorisation method (Jankowiak \& Bieńkowski, 2011).

In addition to the agricultural tax, farms which have forests must pay the forest tax. Until 2003, there were two forms of this tax. The first applied to forests with a management plan, i.e. mainly state forests. The structure of this form of forest tax was similar to the agricultural tax on land. On the other hand, the second type of agricultural tax which applied to peasant forests was based on their area. To the base established in this way, the rate of 0.3 q rye from 1 physical ha of forest was applied. The existence of these two forms of tax resulted in a situation where the forest tax burden for state forests was approximately 2.5 times higher than for peasant forests (Podstawka, 2017). In this situation, taxation of forests was harmonised by the Act on forest tax (2002). Currently, forests, regardless of their owner, are taxed equally. The tax base is the forest area, to which the rate of $0.220 \mathrm{~m}^{3}$ of the wood price is applied. In 2021, this amount is PLN 43.30 from 1 physical ha of forest. It is determined according to the average selling price of wood by forest inspectorates, for the first three quarters of the year preceding the fiscal year.

The third type of tax imposed on farms is the property tax (Act on taxes and local charges, 1991). In the case of farms, it relates to residential buildings only. Its amount is based on the floor area of a residential building. The rates vary according to the decision of the commune council. In 2021, the maximum rate set by the Minister of Finance was PLN 0.85 per $1 \mathrm{~m}^{2}$ of floor area. The structure of the property tax does not allow for the taxpayer's fiscal capacity to be taken into account since the rate of this tax is the same, regardless of the value of $1 \mathrm{~m}^{2}$ of a building or a piece of land. Where the farmer is involved in non-agricultural economic activities, in 2021 the maximum rate of this tax per $1 \mathrm{~m}^{2}$ of a building amounts to PLN 24.84.

As far as taxation of special branches of agricultural production is concerned, the estimates of income from these branches are presented in Table 1.

The standard estimates from the special branches of agricultural production, as presented in Table 1, do not correspond to the economic realities. For example, income from 1 bee family has been estimated at PLN 3.76, from 1 cow - PLN 373.85, from 1 fattener - PLN 47.00, from 1 bovine animal for slaughter - PLN 41.31, etc. They are greatly underestimated. Admittedly, those involved in these activities may pay PIT according to their real income; however, in practice almost $100 \%$ of taxpayers of the special branches tax their incomes according to the standard estimates, thus paying lower taxes ${ }^{1}$.

${ }^{1}$ The study does not include turnover taxes, VAT, and excise tax as they are irrelevant in relation to farm income. 


\section{The level of taxation of farms in the years 2014-2019}

This part of the study will present the economic results of FADN farms in the years 2014-2019. This data will allow us to compare the level of tax burden of the analysed farms with the existing taxes and the effects of introducing various options of income tax. The basic assumption that has been adopted is that the new tax burden should not be higher than the current one. The considerations will be conducted according to the economic size of FADN farms. Tables 1 and 2 show the level of tax burden and its relations to revenues and to agricultural income.

The information in Table 1 shows a clear rule that the burden of agricultural tax increases as the economic power of farms increases. This results from an increase in the area of farms as their economic power improves. According to the FADN (2021) data, in the analysed years very small farms had an area of about 8 ha of agricultural land, small farms - around 15 ha, medium-small farms - around 27 ha, medium-large farms - around 45 ha, and large farms around 83 ha.

The information in Table 2 shows that more than $90 \%$ of the tax burden on the analysed farms was the agricultural tax. Other burdens due to the forest tax and property tax had a small share in the overall tax burden. Assessment of the ratio of the tax burden of farms to the income obtained by these farms is interesting. As mentioned above, the relevant information is presented in Table 3.

From the data contained in Table 3, it appears that the tax burden on income of FADN farms is diversified. It is the largest among small farms and its value is between 14.73 and $67.05 \%$. As the economic situation of the farms improves, the total tax burden in relation to income decreases. This is a result of the area, which increases along with the economic power of the farms, along with the rules of the flat-rate nature of the agricultural tax and its share of more than $90 \%$ in the total tax burden of the analysed farms. The most favourable situation applies to very large farms. Among these farms, the ratios of the tax burden to their income are within $1 \%$. As a rule, the ratios of the total tax burden to income without subsidies among the analysed groups of farms and over the period 2014-2019 remain unchanged.

An important problem in terms of changes in farm taxation is the assessment of the ratios of the total tax burden to farm income with EU subsidies. The relevant information is presented in Table 4.

From the data presented in Table 4, it appears that the share of the total tax burden in farm income with subsidies is lower than its share in income from agricultural activities itself. This is understandable and logical; however, as the economic power of the farms increases, this reduction diminishes. It is the largest for the economically weakest (very small) farms. This means that, among these farms, EU subsidies represent the largest share in their income structure when compared to the economically stronger farms. In the latter, the total tax burden in relation to their income with subsidies is rather nominal. 
From the point of view of new solutions for taxation of farms, i.e. potential taxation of revenues, it is important to assess the share of the agricultural tax and the total tax burden of farms in the value of their commodity production. The relevant information is presented in Table 5.

From the information in Table 4 it appears that the share of the agricultural tax in sales revenues of the FADN farms is nominal. As their economic power increases, the share of this charge in these revenues decreases. This attests to an increase in the efficiency of management and the use of economies of scale on the economically stronger farms. Similar are the ratios of the share of the total tax burden in sales revenues among the analysed farms.

It can therefore be concluded that the tax rates for farm income should be about $1-2 \%$ if these farms are to maintain their existing level of taxation. If taxation of farm income were to be introduced, while maintaining their current state of taxation, the rates of such tax should be between $2-5 \%$.

\section{Conclusion}

The study presents the problems related to potential changes in the taxation of agricultural activities. The problems related to calculating income on farms have been demonstrated. The advantages and disadvantages of the existing taxes paid by farmers have been shown. A positive verification of the research hypotheses has been carried out. All three research hypotheses have been verified positively. The level of taxation of farm income is low. As the economic power of the farm increases, the level of taxation of its income decreases. Over the years 2014-2019, no variation can be observed in the level of taxation of farm income.

The study concludes with a proposal for tax rates. In the case of taxation of farm income, in order to maintain its current level of taxation, the tax rate should be $1-2 \%$. If farm income were to be taxed, the tax rate, which would not increase the current tax burden, should be $2-5 \%$.

\section{References}

Czyżewski, B. (2017). Kierat rynkowy w europejskim rolnictwie. PWN.

FADN. (2014). FADN and Polish FADN. Retrieved 10.09.2021 from: http:// fadn.pl/wp-content/uploads/2014/11/FADN-and-Polish-FADN.pdf.

FADN. (2021). Retrieved 10.09.2021 from https://agridata.ec.europa.eu/extensions/FarmEconomyFocus/FADNDatabase.html.

Jankowiak, J., \& Bieńkowski, J. (2011). Kształtowanie i wykorzystanie zasobów wodnych w rolnictwie. Infrastruktura i Ekologia Terenów Wiejskich, 5, 39-48. Juszczyk, S. (Ed.). (2019). Finanse agrobiznesu. PWN.

Podstawka, M. (Ed.). (2017). Finanse: instytucje, instrumenty, podmioty, rynki, regulacje. PWN. 
Rozporządzenie Ministra Finansów, Funduszy i Polityki Regionalnej z dnia 25 listopada 2020 r. w sprawie norm szacunkowych dochodu z działów specjalnych produkcji rolnej [Ordinance of the Minister for Finance, Funds and Regional Policy of 25 November 2020 on estimated standards for income from special sections of agricultural production] (Dz.U. 2020 poz. 2218) (Poland).

Ustawa z dnia 12 stycznia $1991 \mathrm{r}$. o podatkach i opłatach lokalnych [Act of 12 January 1991 on taxes and local charges] (Dz.U. 1991 nr 9 poz. 31) (Poland).

Ustawa z dnia 15 listopada 1984 r. o podatku rolnym [Act of 15 November 1984 on agricultural tax] (Dz.U. $1984 \mathrm{nr} 52$ poz. 268) (Poland).

Ustawa z dnia 30 października 2002 r. o podatku leśnym [Act of 30 October 2002 on forest tax] (Dz.U. 2002 nr 200 poz. 1682) (Poland).

\section{Acknowledgements}

Author contributions: authors have given an approval to the final version of the article. Authors contributed to this work as follows: M.P. developed the concept and designed the study, M.P. \& E.P. collected the data, M.P. \& E.P. analysed and interpreted the data, M.P. \& E.P. prepared the draft of the article, M.P. \& E.P. revised the article critically for important intellectual content.

Funding: this research was fully funded by the Institute of Agricultural and Food Economics, National Research Institute. 


\section{Appendix}

Table 1.

Standard estimates of income from special branches of agricultural production in 2021

\begin{tabular}{|c|c|c|c|c|}
\hline \multirow{2}{*}{ No. } & \multirow{2}{*}{ Types of crops and production } & \multirow{2}{*}{$\begin{array}{l}\text { Unit of crop area or types } \\
\text { of production }\end{array}$} & \multicolumn{2}{|c|}{$\begin{array}{l}\text { Standard estimate } \\
\text { of annual income }\end{array}$} \\
\hline & & & PLN & gr \\
\hline 1 & Cultivation in heated greenhouses more than $25 \mathrm{~m}^{2}$ & & & \\
\hline a & ornamental plants & $1 \mathrm{~m}^{2}$ & 13 & 15 \\
\hline $\mathrm{b}$ & other & $1 \mathrm{~m}^{2}$ & 4 & 89 \\
\hline 2 & $\begin{array}{l}\text { Cultivation in unheated greenhouses of more than } \\
25 \mathrm{~m}^{2}\end{array}$ & $1 \mathrm{~m}^{2}$ & 3 & 00 \\
\hline 3 & Cultivation in heated plastic tunnels of more than 5 & $0 \mathrm{~m}^{2}:$ & & \\
\hline a & ornamental plants & $1 \mathrm{~m}^{2}$ & 9 & 80 \\
\hline $\mathrm{b}$ & other & $1 \mathrm{~m}^{2}$ & 6 & 01 \\
\hline 4 & $\begin{array}{l}\text { Cultivation of mushrooms and mycelium - more } \\
\text { than } 25 \mathrm{~m}^{2} \text { of cultivation area }\end{array}$ & $1 \mathrm{~m}^{2}$ & 5 & 64 \\
\hline 5 & Slaughter poultry - more than 100 head: & & & \\
\hline $\mathrm{a}$ & chickens & 1 head & & 18 \\
\hline b & geese & 1 head & 1 & 47 \\
\hline c & ducks & 1 head & & 39 \\
\hline $\mathrm{d}$ & turkeys & 1 head & & 95 \\
\hline 6 & Laying poultry - more than 80 head: & & & \\
\hline a & laying hens (in the breeding flock) & 1 head & 3 & 74 \\
\hline b & hens for slaughter (in the breeding flock) & 1 head & 3 & 11 \\
\hline c & geese (in the breeding flock) & 1 head & 2 & 06 \\
\hline d & ducks (in the breeding flock) & 1 head & 3 & 85 \\
\hline e & turkeys (in the breeding flock) & 1 head & 16 & 37 \\
\hline $\mathrm{f}$ & hens (production of table eggs) & 1 head & 2 & 74 \\
\hline 7 & Poultry hatcheries: & & & \\
\hline a & chickens & 1 head & & 01 \\
\hline b & geese & 1 head & & 10 \\
\hline c & ducks & 1 head & & 02 \\
\hline $\mathrm{d}$ & turkeys & 1 head & & 10 \\
\hline 8 & Fur animals: & & & \\
\hline $\mathrm{a}$ & foxes and raccoon dogs & from 1 female of the breeding herd & 51 & 83 \\
\hline $\mathrm{b}$ & minks & $\begin{array}{l}\text { more than } 2 \text { females of the breed- } \\
\text { ing herd }\end{array}$ & 22 & 79 \\
\hline c & polecats & $\begin{array}{l}\text { more than } 2 \text { females of the breed- } \\
\text { ing herd }\end{array}$ & 17 & 63 \\
\hline d & chinchillas & $\begin{array}{l}\text { more than } 2 \text { females of the breed- } \\
\text { ing herd }\end{array}$ & 26 & 94 \\
\hline e & coypus more than 50 females of the breeding herd & from 1 female of the breeding herd & 6 & 21 \\
\hline f & rabbits more than 50 females of the breeding herd & from 1 female of the breeding herd & 6 & 21 \\
\hline 9 & Laboratory animals: & & & \\
\hline a & white rats & 1 head & & 16 \\
\hline $\mathrm{b}$ & white mice & 1 head & & 02 \\
\hline 10 & Silkworms - production of cocoons & $1 \mathrm{dm}^{3}$ & & 38 \\
\hline
\end{tabular}




\begin{tabular}{|c|c|c|c|c|}
\hline \multirow{2}{*}{ No. } & \multirow{2}{*}{ Types of crops and production } & \multirow{2}{*}{$\begin{array}{l}\text { Unit of crop area or types } \\
\text { of production }\end{array}$} & \multicolumn{2}{|c|}{$\begin{array}{l}\text { Standard estimate } \\
\text { of annual income }\end{array}$} \\
\hline & & & PLN & gr \\
\hline 11 & Apiaries of more than 80 families & 1 family & 3 & 76 \\
\hline 12 & In vitro crop cultivation — shelf area & $1 \mathrm{~m}^{2}$ & 225 & 55 \\
\hline 13 & $\begin{array}{l}\text { Breeding of insectivores - cultivation area } \\
\text { of host plants }\end{array}$ & $1 \mathrm{~m}^{2}$ & 187 & 93 \\
\hline 14 & $\begin{array}{l}\text { Breeding of earthworms - area of the breeding } \\
\text { bed }\end{array}$ & $1 \mathrm{~m}^{2}$ & 93 & 97 \\
\hline 15 & Breeding and rearing of other animals outside the fa & arm: & & \\
\hline $\mathrm{a}$ & cows - more than 5 head & 1 head & 375 & 85 \\
\hline $\mathrm{b}$ & calves - more than 10 head & 1 head & 78 & 97 \\
\hline c & $\begin{array}{l}\text { cattle for slaughter - more than } 10 \text { head (exclud- } \\
\text { ing fatteners) }\end{array}$ & 1 head & 41 & 31 \\
\hline d & fatteners - more than 50 head & 1 head & 47 & 00 \\
\hline e & piglets and weaners - more than 50 head & 1 head & 18 & 80 \\
\hline $\mathrm{f}$ & $\begin{array}{l}\text { rearing and breeding of sheep - more than } 10 \\
\text { head }\end{array}$ & from 1 dam & 7 & 53 \\
\hline g & fattening of sheep - more than 15 head & 1 head & 11 & 28 \\
\hline $\mathrm{h}$ & horses for slaughter & 1 head & 563 & 80 \\
\hline i & breeding horses & 1 head of the breeding herd & 451 & 07 \\
\hline j & $\begin{array}{l}\text { farming of aquarium fish - more than } 700 \\
\mathrm{dm}^{3} \text { of aquarium volume calculated according } \\
\text { to the internal length of the edges }\end{array}$ & $1 \mathrm{dm}^{3}$ & 1 & 69 \\
\hline $\mathrm{k}$ & breeding of pedigree dogs & 1 head of the breeding herd & 50 & 76 \\
\hline 1 & breeding of pedigree cats & 1 head of the breeding herd & 18 & 80 \\
\hline
\end{tabular}

Source: Ordinance of the Minister for Finance, Funds and Regional Policy on estimated standards for income from special sections of agricultural production (2020).

Table 2.

Tax burden of farms with the agricultural tax and other taxes

\begin{tabular}{lrrrrrr}
\hline \multicolumn{1}{c}{ Economic classes of FADN farms } & 2014 & 2015 & 2016 & 2017 & 2018 & 2019 \\
\hline Total taxes in PLN/farm & & & & & & 586 \\
very small (EUR 2-8 thousand) & 613 & 639 & 593 & 571 & 563 & 1,004 \\
small (EUR 8-25 thousand) & 1,080 & 1,079 & 1,055 & 999 & 1,005 & 1,741 \\
medium-small (EUR 25-50 thousand) & 1,765 & 1,766 & 1,699 & 1,659 & 1,673 & 2,747 \\
medium-large (EUR 50-100 thousand) & 2,880 & 2,946 & 2,796 & 2,697 & 2,720 & 6,099 \\
large (EUR 100-500 thousand) & 5,721 & 5,546 & 5,314 & 5,193 & 5,555 & 12,863 \\
very large (> EUR 500 thousand) & 7,010 & 4,602 & 5,476 & 6,965 & - & 611 \\
Total taxes in PLN/farm & & & & & & 1,043 \\
very small (EUR 2-8 thousand) & 652 & 671 & 627 & 603 & 593 & 1,795 \\
small (EUR 8-25 thousand) & 1,122 & 1,119 & 1,097 & 1,042 & 1,046 \\
medium-small (EUR 25-50 thousand) & 1,821 & 1,819 & 1,753 & 1,709 & 1,725 \\
medium-large (EUR 50-100 thousand) & 2,943 & 3,008 & 2,852 & 2,756 & 2,774 & 2,802 \\
large (EUR 100-500 thousand) & 5,826 & 5,700 & 5,423 & 5,288 & 5,635 & 6,166 \\
lery large (> EUR 500 thousand) & 7,757 & 5,051 & 7,488 & 7,533 & - & 13,184 \\
\hline
\end{tabular}

Source: FADN (2021). 
Table 3.

Ratio of the total tax burden of farms relative to their income

\begin{tabular}{lrrrrrr}
\hline \multicolumn{1}{c}{ Economic classes of FADN farms } & 2014 & 2015 & 2016 & 2017 & 2018 & 2019 \\
\hline Agricultural income without subsidies in PLN/farm & & & & & \\
very small (EUR 2-8 thousand) & $-3,052$ & $-2,788$ & $-1,815$ & $-1,817$ & $-3,227$ & $-1,057$ \\
small (EUR 8-25 thousand) & 3,747 & 3,864 & 3,001 & 7,075 & 1,560 & 6,134 \\
medium-small (EUR 25-50 thousand) & 25,716 & 21,884 & 23,190 & 37,856 & 28,333 & 36,170 \\
medium-large (EUR 50-100 thousand) & 65,539 & 46,912 & 51,742 & 87,710 & 68,821 & 85,680 \\
large (EUR 100-500 thousand) & 201,350 & 170,083 & 191,404 & 208,416 & 191,924 & 241,208 \\
very large (> EUR 500 thousand) & 479,173 & 768,479 & 677,508 & 574,559 & - & 633,037 \\
\hline Share of the total tax burden in farm income without subsidies in \% & & & & - \\
very small (EUR 2-8 thousand) & - & - & - & - & - & - \\
small (EUR 8-25 thousand) & 29.9 & 28.96 & 36.55 & 14.73 & 67.05 & 17.00 \\
medium-small (EUR 25-50 thousand) & 7.08 & 8.31 & 7.56 & 4.51 & 6.09 & 4.96 \\
medium-large (EUR 50-100 thousand) & 4.50 & 6.41 & 5.51 & 3.14 & 4.03 & 3.27 \\
large (EUR 100-500 thousand) & 2.89 & 3.35 & 2.83 & 2.54 & 2.94 & 2.56 \\
very large (> EUR 500 thousand) & 1.62 & 0.97 & 1.11 & 1.31 & - & 2.08 \\
\hline
\end{tabular}

Source: FADN (2021).

Table 4.

Income of FADN farms with subsidies and the share of the total tax burden in this income

\begin{tabular}{lrrrrrr}
\hline \multicolumn{1}{c}{ Economic classes of FADN farms } & \multicolumn{1}{c}{ 2014 } & \multicolumn{1}{c}{2015} & 2016 & 2017 & 2018 & 2019 \\
\hline Income with subsidies in PLN/farm & & & & & & \\
very small (EUR 2-8 thousand) & 7,922 & 7,880 & 8,707 & 9,472 & 8,778 & 11,707 \\
small (EUR 8-25 thousand) & 24,448 & 25,880 & 25,760 & 31,130 & 26,606 & 32,373 \\
medium-small (EUR 25-50 thousand) & 62,345 & 60,504 & 65,080 & 80,201 & 73,608 & 82,548 \\
medium-large (EUR 50-100 thousand) & 127,562 & 106,092 & 116,748 & 151,258 & 137,974 & 154,261 \\
large (EUR 100-500 thousand) & 320,976 & 264,434 & 288,508 & 313,299 & 302,796 & 350,948 \\
very large (> EUR 500 thousand) & 603,646 & 836,854 & 756,265 & 724,995 & - & $1,030,573$ \\
\hline Ratio of the total tax burden to income with subsidies in \% & & & & & \\
very small (EUR 2-8 thousand) & 8.23 & 8.51 & 7.20 & 6.37 & 6.76 & 5.22 \\
small (EUR 8-25 thousand) & 4.59 & 4.32 & 4.26 & 3.35 & 3.93 & 3.22 \\
medium-small (EUR 25-50 thousand) & 2.92 & 3.00 & 2.69 & 2.13 & 2.34 & 2.17 \\
medium-large (EUR 50-100 thousand) & 2.31 & 2.83 & 2.44 & 1.82 & 2.01 & 1.82 \\
large (EUR 100-500 thousand) & 1.82 & 2.16 & 1.88 & 1.69 & 1.86 & 1.76 \\
very large (> EUR 500 thousand) & 1.29 & 0.60 & 0.99 & 1.04 & - & 1.28 \\
\hline
\end{tabular}

Source: FADN (2021). 
Table 5 .

Share of the agricultural tax and the total tax burden of farms in their sales revenues

\begin{tabular}{lrrrrrr}
\hline \multicolumn{1}{c}{ Economic classes of FADN farms } & \multicolumn{1}{c}{ 2014 } & \multicolumn{1}{c}{2015} & 2016 & 2017 & 2018 & 2019 \\
\hline Sales revenues per farm in PLN & & & & & & \\
very small (EUR 2-8 thousand) & 23,599 & 24,633 & 23,521 & 25,771 & 27,779 & 28,536 \\
small (EUR 8-25 thousand) & 60,917 & 61,815 & 60,358 & 65,859 & 63,156 & 66,739 \\
medium-small (EUR 25-50 thousand) & 153,963 & 153,252 & 148,117 & 161,711 & 161,562 & 169,875 \\
medium-large (EUR 50-100 thousand) & 340,747 & 312,222 & 307,986 & 339,949 & 340,521 & 355,521 \\
large (EUR 100-500 thousand) & $1,166,437$ & $1,099,465$ & $1,147,995$ & $1,001,845$ & $1,018,019$ & $1,067,039$ \\
very large (> EUR 500 thousand) & $3,735,304$ & $4,764,325$ & $4,703,358$ & $4,207,910$ & & $3,733,549$ \\
\hline Share of the agricultural tax in sales revenues in \% & & & & & \\
very small (EUR 2-8 thousand) & 2.60 & 2.59 & 2.52 & 2.21 & 20.3 & 2.05 \\
small (EUR 8-25 thousand) & 1.77 & 1.74 & 1.75 & 1.52 & 1.59 & 1.50 \\
medium-small (EUR 25-50 thousand) & 1.15 & 1.15 & 1.15 & 1.02 & 1.04 & 1.02 \\
medium-large (EUR 50-100 thousand) & 0.85 & 0.94 & 0.91 & 0.79 & 0.80 & 0.77 \\
large (EUR 100-500 thousand) & 0.49 & 0.50 & 0.46 & 0.52 & 0.55 & 0.57 \\
very large (> EUR 500 thousand) & 0.19 & 0.10 & 0.12 & 0.17 & - & 0.34 \\
\hline Share of the total tax burden of farms in sales revenues in $\%$ & & & & & \\
very small (EUR 2-8 thousand) & 2.76 & 2.72 & 2.66 & 2.34 & 2.14 & 2.14 \\
small (EUR 8-25 thousand) & 1.84 & 1.81 & 1.82 & 1.58 & 1.66 & 1.56 \\
medium-small (EUR 25-50 thousand) & 1.18 & 1.19 & 1.18 & 1.06 & 1.07 & 1.06 \\
medium-large (EUR 50-100 thousand) & 0.86 & 0.96 & 0.93 & 0.81 & 0.81 & 0.79 \\
large (EUR 100-500 thousand) & 0.50 & 0.52 & 0.47 & 0.53 & 0.55 & 0.58 \\
very large (> EUR 500 thousand) & 0.21 & 0.11 & 0.10 & 0.18 & - & 0.35 \\
\hline
\end{tabular}

Source: FADN (2021). 


\section{Scheme 1 .}

Method of calculating income on farms according to FADN

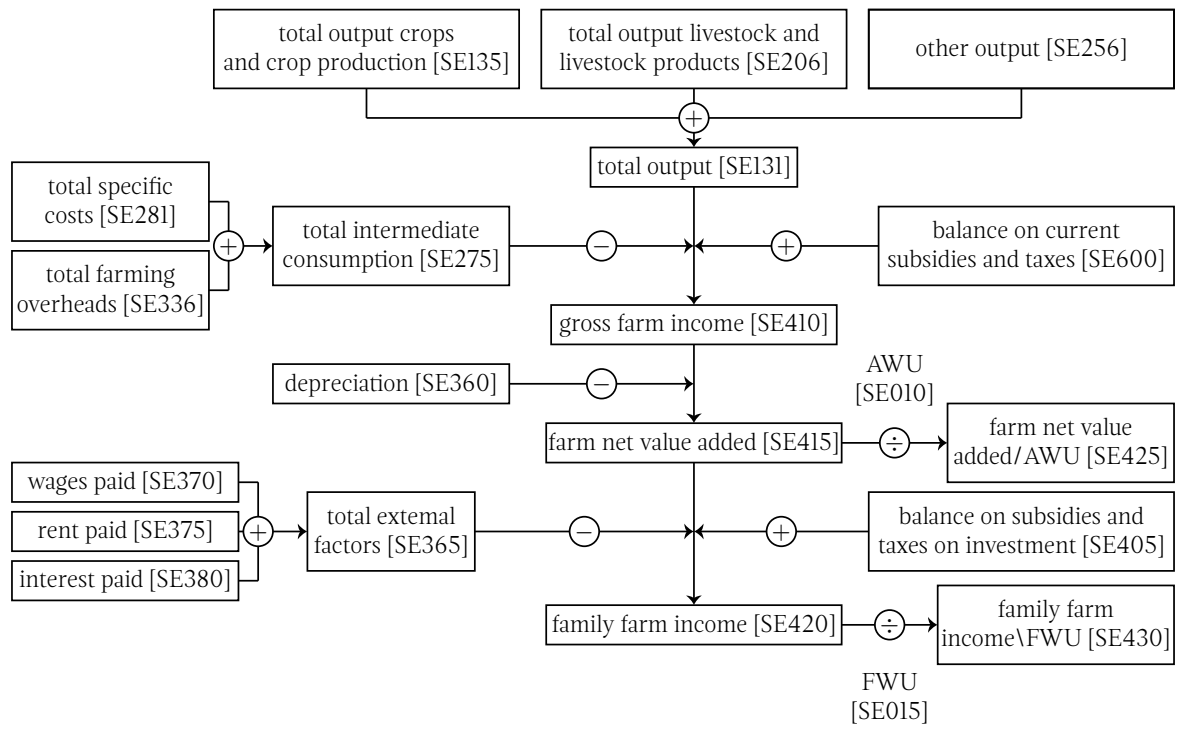

Source: FADN (2014, p. 67).

Scheme 2.

Calculation of farm income according to the "bottom-up" method

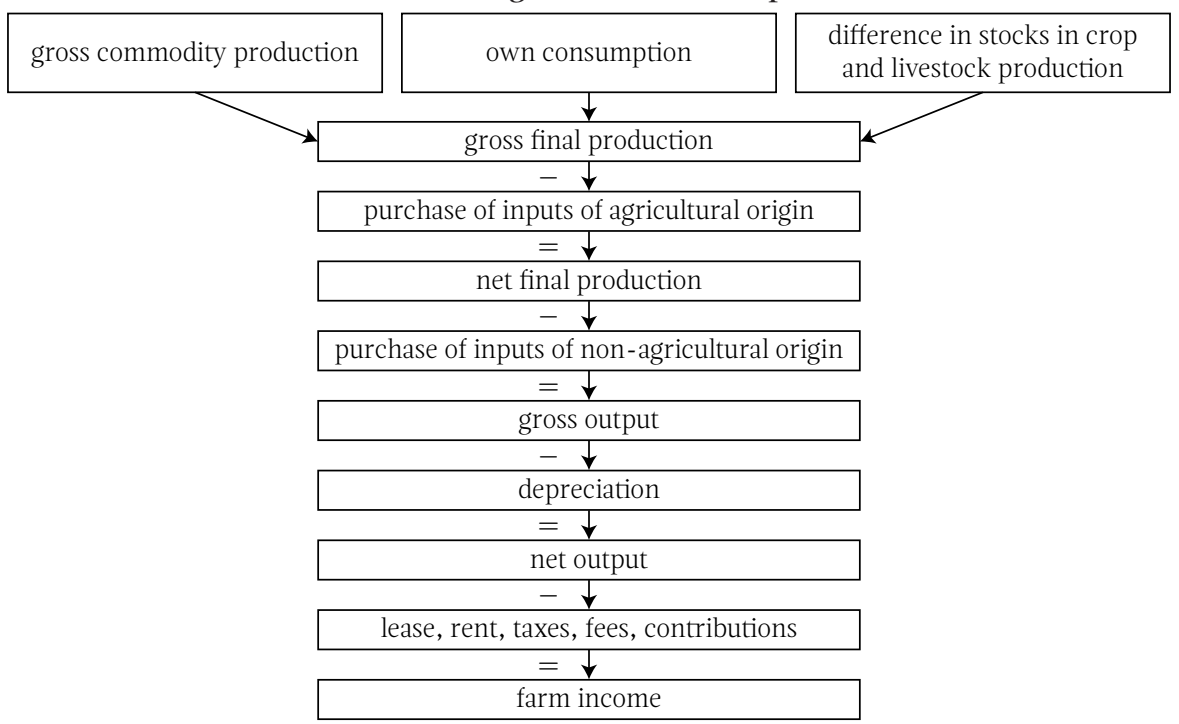

Source: Own preparation. 
